\title{
Study of Micro Grid Hybrid System of Photovoltaic and Diesel Engine
}

\author{
Dwi Novitasari $^{1}$, Y. S. Indartono ${ }^{1,2}$, J. E. Harjono ${ }^{3,2}$, Mlrsyad ${ }^{1,2}$, Tri D. Rachmildha ${ }^{4,5}$ and I. K. Reksowardojo ${ }^{2,3}$ \\ ${ }^{1}$ New and Renewable Energy Research Center, InstitutTeknologi Bandung, Indonesia \\ ${ }^{2}$ Faculty of Mechanical and Aerospace Engineering, InstitutTeknologi Bandung, Indonesia \\ ${ }^{3}$ Combustion Engine and Propulsion System Laboratory, InstitutTeknologi Bandung, Indonesia \\ ${ }^{4}$ Electrical Energy Conversion Research Laboratory, Institut Teknlogi Bandung, Indonesia \\ ${ }^{5}$ School of Electrical Engineering and Informatics, Institut Teknlogi Bandung, Indonesia
}

\begin{abstract}
Indonesia has abundant potentials of new and renewable energy that can be used for electricity generation, especially in rural areas which have no access for grid electricity yet. The energy resources can be from solar, water, biomass or biofuel. Many villagers still use diesel generators to produce electricity in their villages. It is considered expensive because fuel price in rural areas increases 2-3 times than the normal price due to transportation cost. Hybrid system using renewable energy resources is one of the solutions to produce electricity in affordable cost for rural area. The idea is to combine diesel generators and photovoltaic toproduce electricity. Moreover, the diesel engine fuel can be replaced with biofuel. This study will analyze the hybrid system in a small scale which consists of $1 \mathrm{kWp}$ photovoltaic and $3 \mathrm{~kW}$ diesel engine. Electric load power will vary. The system is controlled by a single bidirectional inverter whichconverts power from $\mathrm{DC}$ to $\mathrm{AC}$ and vice versa.
\end{abstract}

\section{Introduction}

Indonesia has many remote areas and small islands which have yet to get access on electricity. Its geographical condition and profile of demand become the main barriers to develop large electricity grid. In 2014, electrification ratio in Indonesia was at $81.70 \%$ [1]. Electrification ratio is defined as the number of households already getting electricity compared to the total number of households in Indonesia. The data show that there were 3,132 of 78,609 villages which have not been electrified yet [2].

On the other hand, Indonesia has various energy sources such as solar, water and bioenergythat can be used for generating electricity in rural areas. In Indonesia, solar energy potential is about $4.8 \mathrm{kWh} / \mathrm{m}^{2} /$ day, and wind velocity is about $3-6 \mathrm{~m} / \mathrm{s}$ [3]. The potential of solar energy is distributed in almost all regions but the potential of wind energy is not available in all regions, but it is only in the eastern area of Indonesia such as Papua, Sulawesi and also in coastal areas [3]. Whereasfor bioenergy, Calophyllum inophyllum (Nyamplung), and Jatrophacurcas are some of the plants in Indonesia that can be used as biofuel. The potential yield of these plants to produce bioenergy is about 4,680 and 1,900-2,500kg of oil/ha per year, respectively [4]. Potential area of land for Jatropha planting in Indonesia is 49,5317 million hectares [5].

These renewable energysourcesare highly recommended to generate electricity in remote areas and small islands. Ministry of Energy and Mineral Resources (MEMR) has built 37 solar power generations across Indonesia, particularly in outer islands and border areas in 2014 with a total capacity of $1,470 \mathrm{~kW}$ for 6,116 households [6]. However, currently most rural communities in Indonesia are generating electricity diesel generators. The problem of using generatorsis the price of diesel fuel and also its impact of air polution. The communities use diesel fuel to operate the generators, while the price of fuel is not cheap in rural areas. It can be 2-3 times more expensive than the price from the government due to the cost of transportation. It causes theelectricity generators able to operate for only 1-3 hours per day, usually in the evening and only for powering the lamps. This is also the reason why using renewable energy, already existing in their areas, is expected to decrease the operational cost and increase the operational time of electricity generation.

Furthermore, the characteristics of renewable energy resources is intermittent in nature, e.g. photovoltaic generatepower depends on the sunlight. When the rainy season comes, there will be only a small energy from sunlight that can be absorbed by photovoltaic. So, the application of renewable energy resources should work together with energy resources that can produce more stable energy. A system which consists of 2 or more resources is called hybrid system. It can consist of all renewable energy or renewable and non renewable energy, such as wind and solar energy, wind, solar and engine using gasoline or biofuel, etc. Considering that 
there are generator sets in rural areas, the idea is to produce electricity generation using hybrid system which consists of engine using biofuel and photovoltaic (PV). $\mathrm{PV}$ is a good option as renewable energy resource in Indonesia because Indonesia is located in tropical area, so it gets sunlight whole year. That is the background of this research. The experiment will focus on observing and analyzing the characteristics of the hybrid system which consists of $1 \mathrm{kWp}$ photovoltaic and $3 \mathrm{~kW}$ diesel engine in a small scale. The experiment was conducted in the Combustion Engines and Propulsion Systems Laboratory, Institut Teknologi Bandung, Indonesia.

\section{Materials}

The whole system in this experiment consists of $1 \mathrm{kWp}$ photovoltaic, $3 \mathrm{~kW}$ diesel engine, bidirectional inverter, solar charge controller, battery, load and monitoring system. There are 20 solar panels each with $50 \mathrm{Wp}$. The diesel engine specification is lister type with the power rating of 3000 watts and operates normally at 650 RPM. This engine can be operated using several types of fuel, not only diesel oil but also biofuel which comes from jatropha oil, palm oil, and coconut oil. The inverter type is bidirectional inverter. It does not only convert from DC to $\mathrm{AC}$ but also from $\mathrm{AC}$ to $\mathrm{DC}$. The specification of inverter is Conext XW+ 7048 by Schneider Electric with continuous power output of $5500 \mathrm{~W}$. The specification of solar charge controller is Conext MPPT 60150 from Schneider Electric as well. The battery capacity is $200 \mathrm{Ah}$ consisting of 8 batterieswith 100Ah, $12 \mathrm{VDC}$, with a configuration of 4 batteries in series to satisfy inverter input voltage, $48 \mathrm{VDC}$ then the batteries connected in parallels so that the capacity become 200Ah. The total load in this experiment is $2500 \mathrm{~W}$ consisting of 5 lamps each at $500 \mathrm{~W}$. ConextCombox (CC) from Schneider Electric is a monitoring and control system at once. It controls inverter and solar charge controller. Monitoring system using $\mathrm{CC}$ can be seen at real time and the data which was captured every minute for 24 hours can be saved in SD card. The hybrid system scheme is shown in Figure 1.

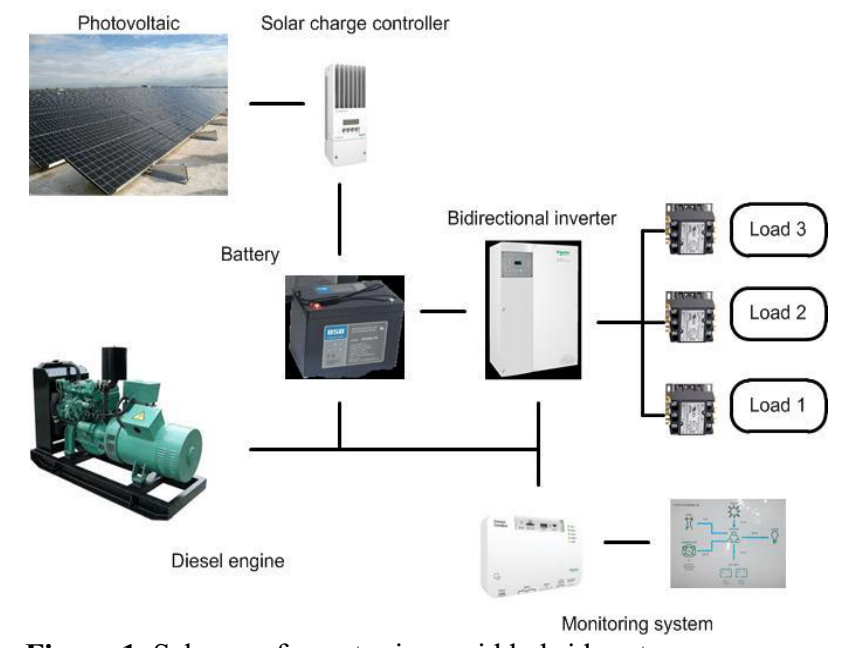

Figure 1. Scheme of smart micro grid hybrid system.

\section{Procedure}

Hybrid experiment started with the setting of diesel engine supply as the base load. Independent variable to be changed was load power. First, load was set at $1000 \mathrm{~W}$, and diesel engine supply of $500 \mathrm{~W}$. The load was increased each with 500 watt after 10 minutes, but keeping diesel engine supply constant. So, it would have 4 variations of load when the diesel engine supply was $500 \mathrm{~W}$, i.e. $1000 \mathrm{~W}, 1500 \mathrm{~W}, 2000 \mathrm{~W}, 2500 \mathrm{~W}$.Then adding the diesel engine supply to become $1000 \mathrm{~W}$ with 3 variations of load, $1500 \mathrm{~W}, 2000 \mathrm{~W}, 2500 \mathrm{~W}$. If the diesel engine produce 1500 watt, the load variations are $2000 \mathrm{~W}$ and $2500 \mathrm{~W}$ and the last was the diesel engine supplywas $2000 \mathrm{~W}$ which is the maximum real output of diesel engine and the load was 2500 watt. The procedures of experiment are shown in Figure 2. There are some parameters that need to be observed: power, current, voltage and frequency. The entire parameters are saved in a monitoring system and can be analyzed.

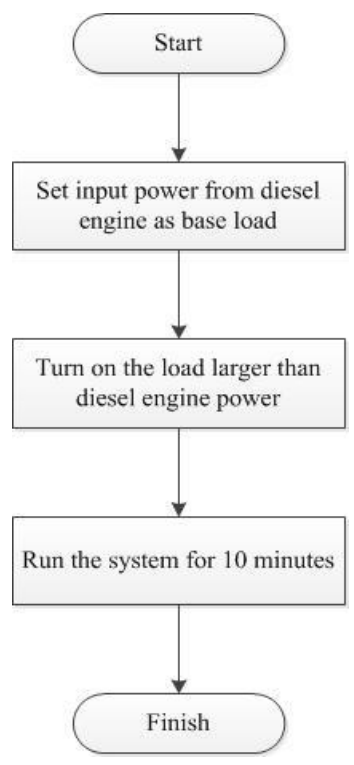

Figure 2. Scheme of experiment.

\section{Results and discussion}

\subsection{PV - Battery - Load}

Before starting the experiment, the measurement of solar radiation at the place of experiment is shown in Figure 3. The data was captured in September $4^{\text {th }} 2015$, about 2 months before the experiment. The data of solar radiation was captured every 5 seconds started from 08:07:15 to 14:39:35. Based on the data, maximum solar radiation was $918.1 \mathrm{~W} / \mathrm{m}^{2}$ at $12: 00$, the minimum value was $88.2 \mathrm{~W} / \mathrm{m}^{2}$ at $14: 00$ and the average was about $683.1 \mathrm{~W} / \mathrm{m}^{2}$.

For the experiment, the first configuration used only battery to supply load. There were 2 battery banks parallelly connected in this experiment. The first battery banks supply power to load and second battery bank receives power from photovoltaic. The result of this experiment is shown in Figure 4 . The battery will supply more power when the load is higher. It means that battery 
needs more power to convert from DC to AC. If the high load exists for a long time, the battery will no longer able to supply the demand. The trend of this result match with the convertion efficiency characteristic shown in Figure 5, which shows that for high load,the convertion efficiency will decrease.However, based on the experiment, the efficiency of inverter is slightly lower than its value as shown in characteristic chart.

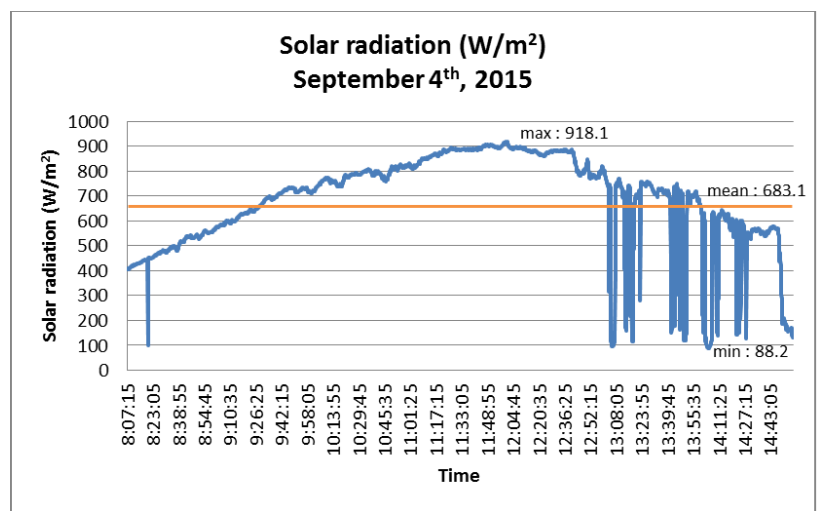

Figure 3. Measured solar radiation in this experiment.

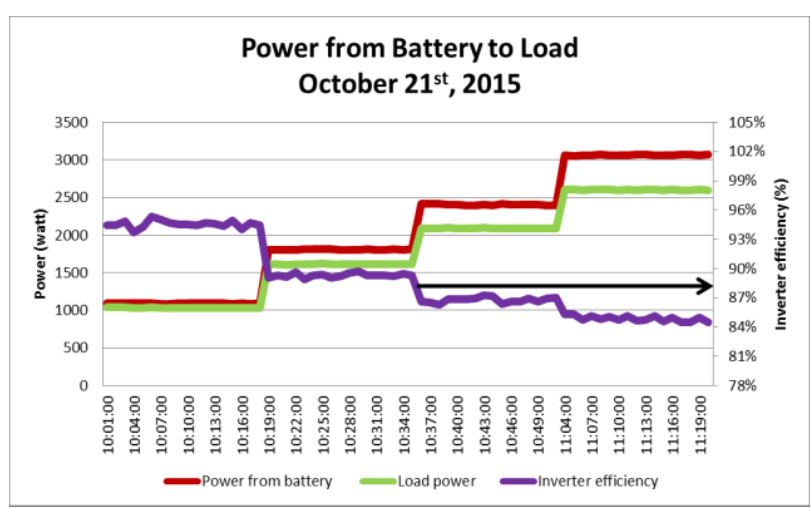

Figure 4. Power supply from battery to load.

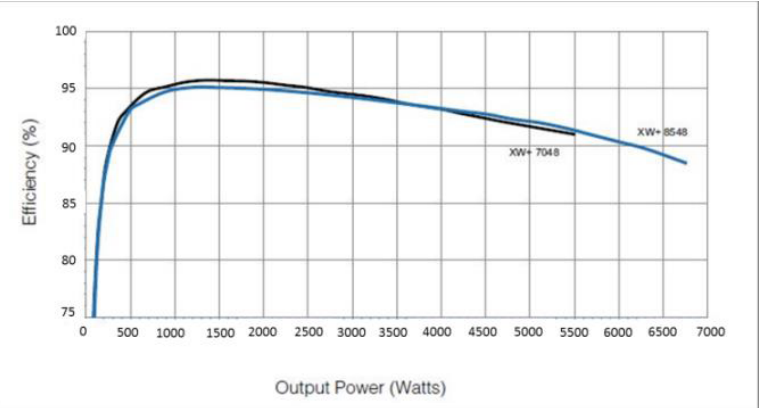

Figure 5. Convertion efficiency characteristic of Inverter Conext XW+ 7048 [7].

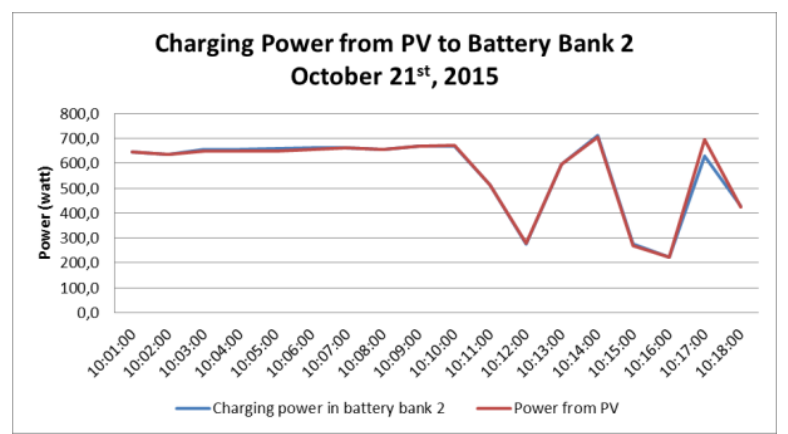

Figure 6. Power from photovoltaic charging battery bank 2 .
Figure 6 shows that the power from photovoltaic was saved in battery bank 2 . The power from photovoltaic pass through the solar charge controller and bidirectional inverter before it was saved in battery bank 2 in DC mode.

\subsection{Diesel engine - Battery - Load}

The second configuration in this experimentused diesel engine to supply load.The supply from diesel engine was adjusted from inverter by defining the limit of maximum current which was allowed by inverter. The output voltage from the generator was 230 volt. Equation (1) shown how to calculate the current. $I$ is current (ampere), $P$ is power (watt) and $V$ is voltage (volt).

$$
I=\frac{P}{V}
$$

Table 1 shows the maximum current that could pass through the inverter. The inverter always searches maximum current value to provide load requirement.

Table 1. Maximum current setting in inverter.

\begin{tabular}{|c|c|}
\hline Load (watt) & $\begin{array}{c}\text { Maximum } \\
\text { current (A) }\end{array}$ \\
\hline 500 & 2.5 \\
\hline 1000 & 4.5 \\
\hline 1500 & 6.7 \\
\hline 2000 & 8.7 \\
\hline 2500 & 10.9 \\
\hline
\end{tabular}

In factin this experiment, the current and voltage was not always fixed as shown in Table 1. Based on captured data, for $500 \mathrm{~W}$ load, the output voltage from generator was about 233-234 volt and the current fixed was 2.3 ampere. The voltage was relatively higher than 230 volt when the load less than $2000 \mathrm{~W}$. For $1500 \mathrm{~W}$ load, the voltage was still 232-233 volt and current was 6.5 ampere, but for the load of $2000 \mathrm{~W}$, the voltage was 228-229 volt and current output was 8.2-8.4 ampere. It happened because the RPM of diesel engine did not fixin 650 RPM. The range value for diesel rotation per minutes was 645655 RPM. Higher or lower than the range value, diesel will not operate in optimum condition.

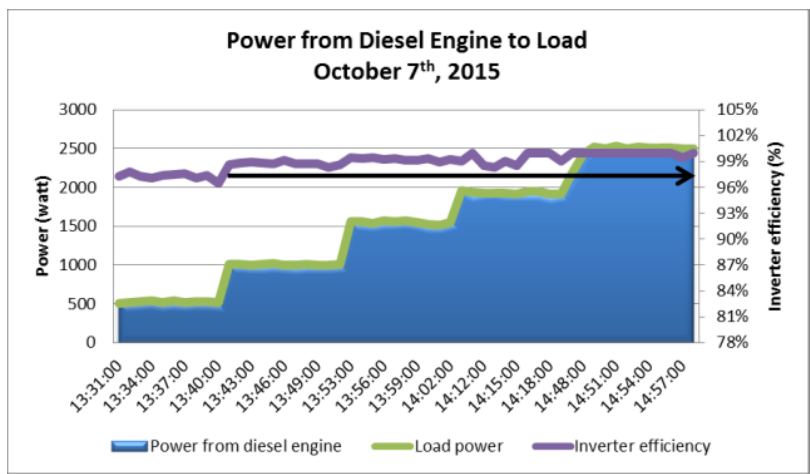

Figure 7. Power supply from diesel engine to load.

Figure 7 shows the results of diesel experiments. The inverter efficiency for diesel engine was different from inverter efficiency for battery. It was due to the converting current from battery. The battery was in 
Direct Current (DC) and the load was in Alternating Current (AC) mode, so there was converting efficiency in this process. It is different from diesel engine where the output from generator was AC mode, the same mode with load. So, basically the power only passed through the inverter, without any process. Figure 7 also shows that diesel engine will perform better when the load is high. The diesel engine capacity was 3000 watt, but the experiments did not set until 3000 watt because the power could not pass through the inverter due to frequency drop.

Figure 8 shows that power from diesel engine charge the battery bank 1 . The diesel engine supplied power more than load requirements meaning that the power from diesel engine was used for charging the battery bank 1. By using 2 battery banks, it was easier to define the power flow from and to battery. In this case battery bank 1 was charged by diesel engine and battery bank 2 was charged by photovoltaic. When battery bank 2 was charged by photovoltaic, voltage in battery bank 1 will follow the battery bank 2 . When battery bank 1 was charged by diesel engine, inverter will automatically prohibit power from PV to charge battery bank 2 and allows diesel engine to charge battery bank 1 . The power from PV might be converted as heat.

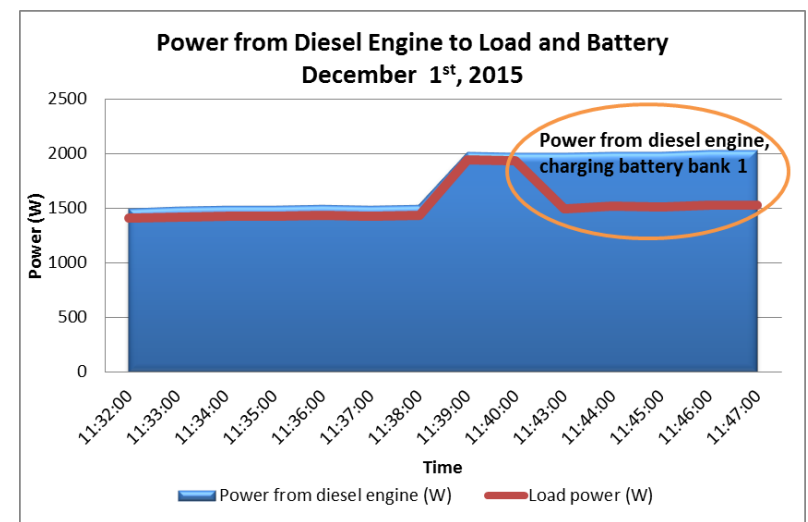

Figure 8. Power supply from diesel engine to load and battery bank 1.

\subsection{Diesel engine - Photovoltaic - Battery - Load}

The last experiment and the most important part set the system in hybrid configuration. The diesel engine was set below the required load. The diesel engine was run to cover baseload whilebatteries which was charged by PVwould cover the rest of power demand from load. The result of these experiment was shown in Figure 9 and Figure 10.

In Figure 9, for the first 10 minutes diesel engine was set to generate power of $2000 \mathrm{~W}$ and the load was $2500 \mathrm{~W}$. The second condition kept the diesel engine supply of $1500 \mathrm{~W}$ with variations of loads at $2000 \mathrm{~W}$ and $2500 \mathrm{~W}$. Until the last experiment, the diesel engine supported $500 \mathrm{~W}$ with variations of loads from $1000 \mathrm{~W}$ to $2500 \mathrm{~W}$.

This experiment started with high supplied power from diesel engine. The power from diesel engine was decrease followed the variations of loads. Based on the experiment, this hybrid system could run well. The load in this experiments used 5 lamps each 500 watt. The supply from diesel engine was controlled by delimit the maximum current. The fuel setting in this diesel engine was controlled manually. It means when there was request from the inverter to supply $500 \mathrm{~W}$, and the maximum current was 2.5 ampere, the governor in diesel engine should be controlled how big the aperture of fuel should be opened. The aperture should be controlled in order to keep the rotation of engine in about 650 rotation per minutes (RPM).

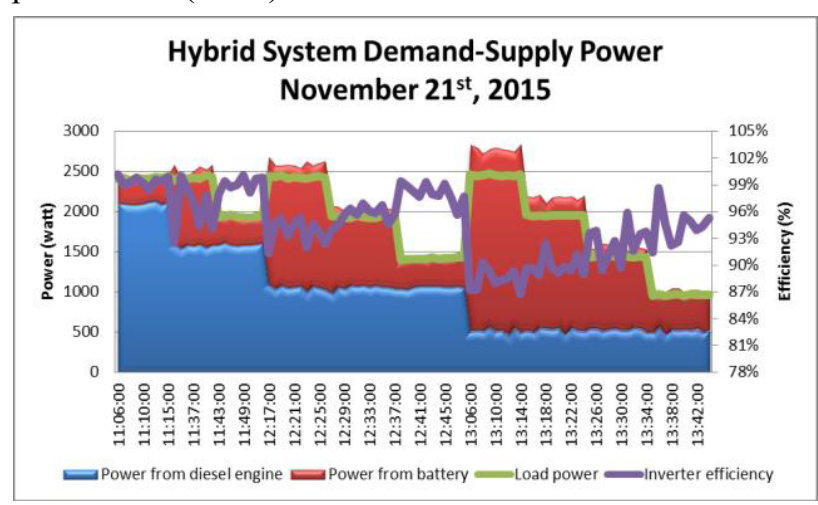

Figure 9. Hybrid power supply when diesel engine power was decrease.

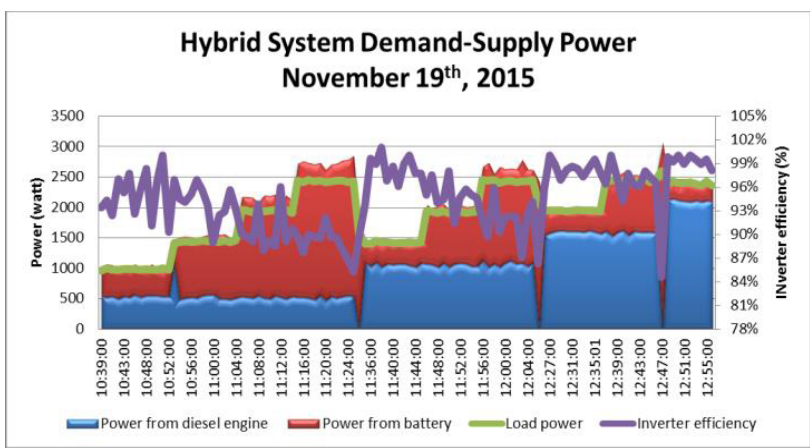

Figure 10. Hybrid power supply when diesel engine power was increase.

Another experiment for hybrid system is shown in Figure 10. The differences between Figure 9 and Figure 10 is power supply from diesel engine. The diesel engine in Figure 9 supplied power from high to low and in Figure 10, supplied power from diesel engine started from low power then increased until its maximum power. Evidently, it has different result. Figure 10 shows that the inverter took time to synchronize with diesel engine when the supply from diesel engine was changed.When it happened, load will be automatically supplied by battery bank 1.

The inverter needs to synchronize with diesel engine because when output power from diesel engine is changed, the RPM of diesel engine will change, which means changing the frequency as well.The inverter has requirement for frequencies from diesel engine. Based on the inverter specification, there are 2 range of frequencies, define as low and high. Low frequency for diesel engine is in range $40-48 \mathrm{~Hz}$ and high frequency is between $52-$ $68 \mathrm{~Hz}$. In Figure 9, the frequency of diesel engine was still in range when the power decreased so that no effect for the load. But in Figure 10, increasing power from diesel engine resulted the diesel engine work harder, so the 
rotation will be lower then the frequency will be lower than the inverter frequency's range. When it happened, the aperture of fuel should be opened larger than before, so that there would be more fuel go to combustion chamber to keep the rotation of diesel engine at about 650 RPM.

\section{Conclusion}

The result of experiments shows that: 1) inverter'sefficiency for system consists of photovoltaicbattery-load is about $83 \%-95 \%$ and 2) inverter's efficiency for system consists of diesel engine-load is about $96 \%-100 \%$. The reasons are by using battery, the inverter must convert the current from $\mathrm{DC}$ to $\mathrm{AC}$, while by using diesel engine, the current passes through the inverter without converting current. Based on the experiments, the efficiency of inverter in converting mode (DC to AC mode) is slightly lower from its specification. In hybrid system, the method on operating diesel engine will affect the whole system. If diesel engine started to deliver power from high mode then the power from diesel engine decreased, the system would stable and operate well. But, if diesel engine started to produce low power, then it needed to increase the power production, the inverter needs to synchronize wth diesel engine. In high power produced by diesel engine, time needed to synchronize between diesel engine and inverter was about 1-3 minutes. In this condition, battery bank will supply the load automatically so the load can operate normally.

The use of diesel engine can increase the efficiency of inverter. On the other hand the use of PV in this system is proven reduce the consumption of fuel significantly. Batteries are still necessary in stabilizing system. It is good to use 2 battery banks because it will be easier to capture the power flow from diesel engine or PV. In addition, using 2 battery banks in parallel is good forthe reliability of the whole system than single battery bank.

\section{Acknowledgment}

This research received fund from New and Renewable Energy Research Center, Institut Teknologi Bandung and National Strategic Research, Ministry of Research and The Ministry of Higher Education, Indonesia, 2015.

\section{References}

1. PT PLN (Persero), Statistik PLN 2014, (2015)

2. PT Perusahaan Listrik Negara (Persero), Rencana Usaha Penyediaan Tenaga Listrik (RUPTL) 2015 2024, (2015)

3. Badan Pengkajian dan Penerapan Teknologi, Outlook Energi Indonesia 2014, Jakarta, (2014)

4. M. Irsyad, Y. S. Indartono, A. Suwono, and A. D. Pasek, Thermal Characteristics of Non-edible Oils as Phase Change Materials Candidate to Application of Air Conditioning Chilled Water System, IOP Conf. Ser. Mater. Sci. Eng., 88:012051, (2015)

5. A. Kuncahyo, Priyohadi Fathallah and Semin, Analisa Prediksi Potensi Bahan Baku Biodiesel Sebagai Suplemen Bahan Bakar Motor Diesel di Indonesia, J. Tek. Pomits, 2(1):1-5, (2013)

6. Ferial, 2014, Pulau Terluar Dan Perbatasan Dapat 37 Unit PLTS, 2015. [Online]. Available: http://ebtke.esdm.go.id/post/2015/01/21/763/2014.pu lau.terluar.dan.perbatasan.dapat.37.unit.plts

7. Schneider Electric, Owner's Guide Conext ${ }^{T M} X W$ Inverter / Charger, (2014) 